\title{
Ewolucja polskiego systemu kierowania i dowodzenia siłami zbrojnymi w Polsce w latach 1989-2014
}

\author{
Evolution of the Polish Command and Control \\ System for Armed Forces in Poland in 1989-2014
}

\section{- Abstrakt •}

Kluczowym elementem systemu bezpieczeństwa narodowego jest podsystem określający zasady kierowania i dowodzenia siłami zbrojnymi. Obowiązujący w danym państwie system kierowania i dowodzenia wojskiem determinowany jest jego organizacją, stopniem rozwoju, formą rządów oraz panującym w nim ustrojem politycznym i społeczno-gospodarczym. Niebagatelną rolę odgrywają także: tradycja, dziedzictwo historyczne oraz dorobek intelektualny i materialny, a nade wszystko usytuowanie geopolityczne. Przedstawiany artykuł prezentuje ewolucję poglądów i rozwiązań ustrojowych oraz normatywnych w zakresie budowania nowego systemu kierowania i dowodzenia siłami zbrojnymi uwzględniających zmienne warunki zewnętrzne $\mathrm{i}$ wewnętrzne na przestrzeni od początków transformacji ustrojowej w Polsce zapoczątkowanej w 1989 roku, aż po aktualnie funkcjonujący system obowiązujący od 1 stycznia $2014 \mathrm{r}$.

Słowa kluczowe: system bezpieczeństwa narodowego; system kierowania i dowodzenia siłami zbrojnymi; zwierzchnik sił zbrojnych; naczelny dowódca sił zbrojnych

\section{- Abstract •}

The subsystem defining the principles of command and control of armed forces is a key element of the national security system. The command and control system in a given country is determined by its organization, degree of development, form of government and the political and socio-economic system prevailing in it. Tradition, historical heritage, as well as intellectual and material achievements, and above all the geopolitical position, also play a crucial role. This article presents the evolution of political and normative views and solutions in the area of building a new system of command and control of armed forces, taking into account the changing external and internal conditions from the beginning of the political transformation in Poland, initiated in 1989, to the currently functioning system, in force since January 1, 2014.

Keywords: national security system; the command and control system of the armed forces; the superior of the armed forces; the commander-in-chief of the armed forces 
Kluczową rolę wśród podsystemów obronnych, składających się na system bezpieczeństwa narodowego, odgrywa system kierowania i dowodzenia siłami zbrojnymi. Zazwyczaj wyznacza się dla niego cztery obszary zadaniowe. Do pierwszego zalicza się monitorowanie zagrożeń, z uwzględnieniem skali, rodzaju i miejsca ich występowania. Drugi obejmuje zapobieganie powstawaniu zagrożeń zarówno na własnym terytorium, jak i poza jego granicami. Trzeci obszar stanowią działania związane z usuwaniem skutków zagrożeń, gdy nie udało się im zapobiec. Czwarty obszar skupia się na kierowaniu obroną państwa w razie bezpośredniej agresji militarnej (Biuro Bezpieczeństwa Narodowego, 2013).

Obowiązujący $\mathrm{w}$ danym państwie system kierowania i dowodzenia siłami zbrojnymi bywa zazwyczaj odzwierciedleniem organizacji konkretnego państwa, stopnia jego rozwoju, formy rządów oraz panującego w nim ustroju politycznego i społeczno-gospodarczego, ale także tradycji, dziedzictwa historycznego, dorob$\mathrm{ku}$ intelektualnego i materialnego, czy wreszcie usytuowania geopolitycznego. W Polsce istotne zmiany w kształtowaniu własnego systemu kierowania i dowodzenia siłami zbrojnymi spowodowane były w głównej mierze zasadniczą transformacją ustrojową państwa po 1989 roku. Odzyskanie pełnej suwerenności wymagało nie tylko przebudowy ustrojowej państwa, ale również ukształtowania na nowo systemów zapewniających państwu bezpieczeństwo wewnętrzne i zewnętrzne przed potencjalnymi zagrożeniami. W procesie tym kluczową rolę odgrywało nowe usytuowanie sił zbrojnych w strukturze organizacji państwowej oraz zbudowanie nowych mechanizmów sprawowania zwierzchnictwa i dowodzenia nimi, z uwzględnieniem interesów narodowych (Kitler, Czuryk, Karpiuk, 2012, s. 88). W pierwszym rzędzie konieczne stało się zerwanie więzi łączących nasze wojsko z systemem dowodzenia Układu Warszawskiego. Siły zbrojne miały stać się nie jedynym elementem systemu obronnego kraju, ale ważnym jego współuczestnikiem. Budując demokratyczne państwo prawne, należało zapewnić apolityczność żołnierzy, a organom państwa cywilną kontrolę nad armią.

Transformacja ustrojowa w Polsce zapoczątkowana w czerwcu 1989 r. pierwszymi od zakończenia II wojny światowej częściowo wolnymi wyborami wywarła również ogromny wpływ na określenie pozycji ustrojowej sił zbrojnych w państwie oraz na kształtowanie systemu kierowania i dowodzenia nimi w nowych realiach politycznych. Istniejący przed 1989 rokiem system determinowany był pozostawaniem naszego kraju w sowieckiej strefie wpływów, w tym także w sferze militarnej. W owym czasie dowodzenie wojskiem polskim, podobnie jak w innych krajach tzw. Bloku Wschodniego, ukształtowane było na wzorcach narzuconych przez Związek Sowiecki (Kulisz, 2008, s. 99 i n.). Dowodzenie żołnierzami armii polskiej podporządkowane było w pełni ogniwom dowódczym Układu Warszaw- 
skiego, przede wszystkim Dowództwu Zjednoczonych Sił Zbrojnych z siedzibą w Moskwie, a w rzeczywistości Zarządowi X Sztabu Generalnego Związku Socjalistycznych Republik Radzieckich.

Konstytucja Polskiej Rzeczypospolitej Ludowej z 1952 r. w sposób bardzo ogólny formułowała zasady kształtowania systemu kierowania i dowodzenia siłami zbrojnymi. Wśród kompetencji Rady Ministrów wspomniano jedynie o sprawowaniu ogólnego kierownictwa w dziedzinie obronności kraju i organizacji sił zbrojnych PRL. Nie odniesiono się niemal zupełnie do kwestii dowodzenia. Wśród uprawnień Rady Państwa wspomniano tylko o obsadzie stanowisk wojskowych (Konstytucja Polskiej Rzeczypospolitej Ludowej uchwalona przez Sejm Ustawodawczy w dniu 22 lipca 1952 r.). Przede wszystkim zabrakło wskazania organu państwa wykonującego funkcje zwierzchnictwa nad siłami zbrojnymi. Pewnego uszczegółowienia w kwestii kierowania i dowodzenia siłami zbrojnymi dokonano w uchwalonej w listopadzie 1967 r. ustawie obronnej (Ustawa z dnia 21 listopada 1967 r. o powszechnym obowiązku obrony Polskiej Rzeczypospolitej Ludowej). W jej art. 3 określone zostały zadania sił zbrojnych. Zaliczono do nich stanie na straży suwerenności i niepodległości narodu polskiego oraz jego bezpieczeństwa i pokoju. Kierowanie obronnością spoczywało na Radzie Ministrów, co wynikało z przepisów konstytucyjnych, wykonywane za pośrednictwem Komitetu Obrony Kraju, będącego wyspecjalizowanym komitetem rządu (art. 5). Jako dowódcę armii polskiej wskazano ministra obrony narodowej, stwierdzając, że „stoi na czele Sił Zbrojnych Polskiej Rzeczypospolitej Ludowej” (art. 9 ust. 2), pełniąc jednocześnie funkcję naczelnego organu administracji państwowej w sprawach obronnych i wojskowych.

Jakościowa zmiana dokonała się wraz z restytucją urzędu Prezydenta Polskiej Rzeczypospolitej Ludowej. W noweli konstytucyjnej z 7 kwietnia 1989 r. głowę państwa wyposażono w uprawnienia zwierzchnika Sił Zbrojnych PRL (Ustawa z dnia 7 kwietnia 1989 r. o zmianie Konstytucji Polskiej Rzeczypospolitej Ludowej). Chociaż nie w pełni. Utworzono nowe stanowisko dowódcze - naczelnego dowódcę sił zbrojnych PRL, ale prawo jego mianowania zastrzeżono dla Sejmu. Jedynie w przypadku, gdy nie obradował, mianowania mógł dokonać prezydent. Sprecyzowanie uprawnień zwierzchnika nastąpiło w ustawie przekazującej dotychczasowe kompetencje Rady Państwa prezydentowi (Ustawa z dnia 29 maja 1989 r. o przekazaniu dotychczasowych kompetencji Rady Państwa Prezydentowi Polskiej Rzeczypospolitej Ludowej i innym organom państwowym). Dzięki zawartym tam przepisom prezydent PRL określał główne kierunki rozwoju sił zbrojnych oraz ich przygotowania do obrony państwa. Istotniejsze jednak było nadanie prezydentowi uprawnienia do mianowania i zwalniania szefa Sztabu Generalnego 
Wojska Polskiego, dowódców okręgów wojskowych i rodzajów sił zbrojnych. Nie była to co prawda prerogatywa osobista głowy państwa, bo konieczny był do tego wniosek ministra obrony narodowej, ale w ten sposób organy państwa polskiego odzyskiwały suwerenność w kierowaniu i dowodzeniu armią polską.

Konieczność zbudowania narodowego systemu kierowania i dowodzenia siłami zbrojnymi została wyartykułowana w Doktrynie Obronnej Rzeczypospolitej Polskiej podpisanej w lutym 1990 r. (Uchwała Komitetu Obrony Kraju z dnia 21 lutego 1990 r. w sprawie Doktryny Obronnej Rzeczypospolitej Polskiej). Należy zauważyć, że koncepcja tego systemu tkwiła jeszcze w dotychczasowych realiach polityczno-militarnych wyznaczanych przez przynależność Polski do Układu Warszawskiego. W wypadku wojny miało nastąpić wydzielenie odpowiedniego zgrupowania operacyjnego pozostającego pod narodowym dowództwem, ale działającym w składzie Zjednoczonych Sił Zbrojnych Państw-Stron Układu Warszawskiego. Zgrupowanie to mogło być użyte zgodnie z interesem narodowym, a wpływ na podjęcie decyzji o ich użyciu zachowywali przedstawiciele Wojska Polskiego, reprezentujący w Zjednoczonych Siłach Zbrojnych władze Rzeczypospolitej Polskiej. Z pewnością Doktryna próbowała wyznaczać kierunki kształtowania narodowego systemu kierowania i dowodzenia siłami zbrojnymi, jednakże w istniejących wówczas realiach dominującą rolę nadal odgrywało dowództwo sowieckie, choć i w tym zakresie zaczęły pojawiać się sugestie zmiany istniejącego stanu rzeczy (Onyszkiewicz, 1999, s. 93 i n.). Należy zauważyć, że w tym czasie aktywność struktur Układu Warszawskiego zaczęła powoli zamierać. 25 lutego 1991 r. w Budapeszcie ministrowie spraw zagranicznych i obrony podpisali umowę o zaprzestaniu współpracy wojskowej oraz rozwiązaniu wspólnego dowództwa. Ostatecznie w dniu 1 lipca tego roku w Pradze państwa tworzące Układ Warszawski podpisały protokół o utracie mocy obowiązującej traktatu powołującego do życia ten blok wojskowy (Protokół sporządzony w Pradze dnia 1 lipca 1991 r. o utracie mocy Układu o przyjaźni, współpracy i pomocy wzajemnej, podpisanego w Warszawie dnia 14 maja 1955 r., oraz Protokołu o przedłużeniu jego obowiązywania, podpisanego w Warszawie dnia 26 kwietnia 1985 r.). Wszedł on w życie z dniem 18 lutego 1993 r. (Oświadczenie rządowe z dnia 25 maja 1993 r. w sprawie wejścia w życie Protokołu sporządzonego w Pradze dnia 1 lipca 1991 r. o utracie mocy Układu o przyjaźni, współpracy i pomocy wzajemnej, podpisanego w Warszawie dnia 14 maja 1955 r., oraz Protokołu o przedłużeniu jego obowiązywania, podpisanego w Warszawie dnia 26 kwietnia 1985 r.). Z tym dniem formalnie przestały istnieć Zjednoczone Siły Zbrojne i wspólne dowództwo.

Likwidacja wschodniego bloku militarnego stworzyła całkowicie nową sytuację. Przede wszystkim należało zbudować od podstaw nowy system kierowania 
i dowodzenia siłami zbrojnymi w oparciu na ukształtowanym systemie organów ustrojowych państwa, szczególnie zaś w zakresie bezpieczeństwa zewnętrznego państwa i obronności. Kwestie te miała rozwiązać nowa konstytucja. Prace nad nią rozpoczął już Sejm kontraktowy (X kadencji), powołując 7 grudnia 1989 r. Komisję Konstytucyjną. Jej odpowiednik powołał również Senat. Mimo złożenia kilkunastu projektów parlament do końca skróconej kadencji nie zdołał uchwalić nowej ustawy zasadniczej ${ }^{1}$.

W międzyczasie próbowano dokonać ukształtowania systemu kierowania i dowodzenia siłami zbrojnymi opartego na rozwiązaniach ustawowych. Do 1990 roku, jak już wspomniano, dominującą pozycję w strukturze organizacyjnej sił zbrojnych miał minister obrony narodowej, którą wyznaczały regulacje ustawy o powszechnym obowiązku obrony Polskiej Rzeczypospolitej Ludowej z 1967 r. Określony tam zakres jego zadań nadawał mu bardzo szerokie kompetencje w zakresie obronności. Minister obrony narodowej dowodził siłami zbrojnymi, ale wykonywał wynikające stąd zadania za pośrednictwem szefa Sztabu Generalnego Wojska Polskiego, dowódców okręgów wojskowych i dowódców rodzajów sił zbrojnych (Wasilewski, Kuleta, 2003, s. 213 i n.). Zmiany w organizacji i funkcjonowaniu ministra obrony narodowej zainicjowało powołanie do życia przez premiera Tadeusza Mazowieckiego Międzyresortowej Komisji do spraw Reformy w Organizacji Obrony Narodowej (Zarządzenie nr 67/PRM z dnia 29 grudnia 1990 r. w sprawie powołania Międzyresortowej Komisji do Spraw Reform w Organizacji Obrony Narodowej)2. Prace Komisji trwały do czerwca 1991 r., a jej ustalenia i rekomendacje były omawiane na posiedzeniu rządu w dniu 9 lipca. Komisja rekomendowała podział Ministerstwa Obrony Narodowej na dwie części: cywilno-wojskową i wojskową. Zakładano, że resortem będzie kierował cywilny polityk. Natomiast dowodzenie siłami zbrojnymi zostanie powierzone szefowi Sztabu Generalnego, którego stanowisko zostanie przeformowane i połączone z nowo utworzonym stanowiskiem generalnego inspektora sił zbrojnych, co stanowiło w pewnym sensie nawiązanie do rozwiązań z okresu II Rzeczypospolitej. Podjęte wówczas przez Radę Ministrów decyzje zostały spisane w protokole usta-

${ }^{1}$ Kadencja Sejmu X kadencji miała trwać do czerwca 1993 r. Jednakże w dniu 9 marca 1991 r. Sejm podjął uchwałę o samorozwiązaniu parlamentu z dniem poprzedzającym dzień kolejnych wyborów do Sejmu i Senatu (MP z 1991 r., nr 9, poz. 63). Prezydent RP Lech Wałęsa wyznaczył termin kolejnych wyborów parlamentarnych na dzień 27 października 1991 r. (Zarządzenie Prezydenta Rzeczypospolitej Polskiej z dnia 3 lipca 1991 r. w sprawie zarządzenia wyborów do Sejmu i Senatu Rzeczypospolitej Polskiej). Zob. też: Lech, 2016.

2 Zespół ten nazywano potocznie komisją Żabińskiego, gdyż jej pracami kierował minister Krzysztof Żabiński, ówczesny szef Urzędu Rady Ministrów. 
leń nr 32/91 (Padzik, 2011, s. 99). Stały się one podstawą opracowania projektu ustawy o zmianach w zakresie działania Ministra Obrony Narodowej oraz zasad kierowania i dowodzenia Siłami Zbrojnymi Rzeczypospolitej Polskiej (Druk Sejmu Rzeczypospolitej Polskiej nr 994 z dnia 19 lipca 1991 r.).

Główną przesłanką determinującą zainicjowanie prac legislacyjnych było dążenie do zbudowania prawnych ram dla cywilnego zwierzchnictwa nad siłami zbrojnymi. Ówczesnemu rządowi zależało na rozdzieleniu funkcji administracyjnych i politycznych od zadań czysto wojskowych. W projektowanych rozwiązaniach minister obrony narodowej stawał się przełożonym wszystkich żołnierzy sił zbrojnych oraz pracowników cywilnych wojska. Na jego wniosek prezydent Rzeczypospolitej, jako zwierzchnik sił zbrojnych, mianował i zwalniał szefa Sztabu Generalnego oraz dowódców rodzajów sił zbrojnych. Do jego zadań należeć miało kierowanie siłami zbrojnymi w zakresie ich rozwoju, szkolenia i przygotowania obronnego. Miał je wykonywać przy pomocy podległego mu szefa Sztabu Generalnego Wojska Polskiego, zajmującego jednocześnie stanowisko generalnego inspektora sił zbrojnych. Przyjęcie takiej koncepcji miało zapewnić, że zawodowa kadra oficerska zostałaby zwolniona z obowiązku wykonywania wielu funkcji związanych z kwestiami administracyjno-finansowymi, zaopatrzeniowymi, inwestycyjnymi, socjalno-bytowymi i kulturalnymi, które przeszłyby do sfery cywilnej (Sprawozdanie..., 1991, łam 554 i n.). Mimo że większość klubów parlamentarnych poparła zasadnicze tezy przedstawionego projektu, a pozytywnie o projekcie wypowiedziała się też sejmowa Komisja Obrony Narodowej, Sejm nie zdołał uchwalić ustawy. Główną przeszkodą stał się narastający spór o model sprawowania władzy w Polsce. W owym czasie ścierały się poglądy zwolenników modelu prezydenckiego i parlamentarno-gabinetowego. W tym kontekście toczyła się również dyskusja o przyszłym kształcie sił zbrojnych oraz miejscu i roli szefa Sztabu Generalnego w dowodzeniu wojskiem (Medykowski, Szulc, Zalewski, 2003, s. 354 i n.). W pierwszym okresie transformacji nie potrafiono dokonać zmian w zakresie działania ministra obrony narodowej ani w zasadach kierowania i dowodzenia siłami zbrojnymi. Zabrakło woli politycznej i myślenia propaństwowego.

Niemniej udało się dokonać zmiany systemu dowodzenia na średnim szczeblu. Przez cały okres naszej przynależności do Układu Warszawskiego kraj podzielony był na trzy okręgi wojskowe: Warszawski Okręg Wojskowy, Pomorski Okręg Wojskowy i Śląski Okręg Wojskowy. Stanowiły one organ wykonawczy ministra obrony narodowej w zakresie spraw operacyjno-obronnych i specjalnej administracji niezespolonej w sprawach wojskowych. W okresie ewentualnej wojny dowódca okręgu wojskowego był odpowiedzialny za sprawne przeprowadzenie mobilizacji na podległym sobie terenie i wojenne rozwinięcie jednostek stacjonujących na 
obszarze okręgu do formatu armii. Wszystkie okręgi, po rozwinięciu, w planach sowieckich tworzyły Front Nadmorski (Polski) ${ }^{3}$. Zmiana sytuacji obronnej Polski po likwidacji Układu Warszawskiego i upadku Bloku Wschodniego spowodowała konieczność przeformowania okręgów wojskowych. Rada Ministrów zdecydowała 5 czerwca 1992 r. o utworzeniu Krakowskiego Okręgu Wojskowego ${ }^{4}$, obejmującego 14 ówczesnych województw południowo-wschodniej Polski. Nowy okręg wojskowy podjął wykonywanie swoich obowiązków w październiku 1992 r. (Rozporządzenie Rady Ministrów z dnia 5 czerwca 1992 r. w sprawie utworzenia okręgów wojskowych oraz określenia ich siedzib i terytorialnego zasięgu działania).

Przeformułowano również charakter rozwinięcia wojennego okręgów. Według nowych zasad rozwijać się miały nie do ugrupowań armijnych, lecz korpuśnych. Po rozwinięciu okręgi: Pomorski, Warszawski i Śląski miały wystawić po korpusie złożonym z trzech dywizji zmechanizowanych. Natomiast okręg krakowski miał wystawić korpus, w skład którego miały wchodzić dywizja kawalerii powietrznej oraz trzy samodzielne brygady. Ponadto Siły Powietrze wystawiały korpus lotnictwa operacyjnego i dwa korpusy obrony powietrznej, a marynarka wojenna trzy flotylle (Kajetanowicz, 2013, s. 114 i n.).

W kolejnych latach, mimo składanych deklaracji, nie podjęto żadnej inicjatywy ustawodawczej w odniesieniu do sfery kierowania i dowodzenia siłami zbrojnym. Jedynym wyjątkiem były regulacje zawarte w tzw. małej konstytucji (Ustawa konstytucyjna z dnia 17 października 1992 r. o wzajemnych stosunkach między władzą ustawodawczą i wykonawczą Rzeczypospolitej Polskiej oraz o samorządzie terytorialnym). Określając w art. 28 i 35 kompetencje prezydenta Rzeczypospolitej, powierzono mu strzeżenie suwerenności i bezpieczeństwa państwa oraz nienaruszalności i niepodzielności jego terytorium. Zadania te wykonywał

${ }^{3}$ Koncepcja Frontu Nadmorskiego, zwanego także Polskim, pojawiła się w 1950 r. po zakończeniu w maju tego roku ćwiczeń wojsk sowieckich i polskich. Tworzące go trzy armie polskie miały za zadanie obronę wybrzeża bałtyckiego przed desantem wojsk NATO, a następnie zajęcie północnych obszarów Niemiec i Danii, by umożliwić flocie sowieckiej swobodne przemieszczanie się na Morze Północne i Atlantyk. Utworzenie Frontu Nadmorskiego zawarto w Protokole uzgodnień pomiędzy rządami PRL i ZSRR podpisanym w Moskwie po rozmowach w dniach 4-7 stycznia 1955 r. Ustalenia protokołu obowiązywały również po podpisaniu traktatu powołującego do życia Układ Warszawski. Koncepcja Frontu Nadmorskiego zdezaktualizowała się wraz z upadkiem Układu Warszawskiego w 1991 r. (Piotrowski, 2000, s. 24).

${ }^{4}$ Stanowiło to do pewnego stopnia powrót do struktury istniejącej w wojsku polskim w okresie przed wejściem do Układu Warszawskiego. Początkowo Krakowski Okręg Wojskowy został utworzony na podstawie rozkazu Naczelnego Dowództwa Wojsk Polskich nr 23/Org z dnia 1 lutego 1945 r., odtwarzającego powojenną organizację wojska. Nawiązywano wówczas do tradycji przedwojennych dowództw okręgów wojskowych. Okręg krakowski otrzymał oznaczenie V DOW. W roku 1949 został przemianowany na Krakowski Okręg Wojskowy, a w 1954 został rozformowany. 
jako najwyższy zwierzchnik sił zbrojnych. Rozszerzeniu uległy jego uprawnienia w stosunku kształtowania kadry dowódczej w wojsku. Już nie na wniosek, a w porozumieniu z ministrem obrony narodowej mianował i zwalniał szefa Sztabu Generalnego Wojska Polskiego, który nie uzyskał konstytucyjnego stanowiska generalnego inspektora sił zbrojnych. Ponadto na wniosek szefa resortu obrony mianował i zwalniał zastępców szefa Sztabu Generalnego, dowódców rodzajów sił zbrojnych oraz dowódców okręgów wojskowych. Wcześniej była to samodzielna kompetencja ministra. $\mathrm{Na}$ czas wojny prezydent mianował i zwalniał naczelnego wodza. Ustrojodawca nie wskazał jednak, komu ta funkcja mogła być powierzona.

Wkrótce po uchwaleniu ustawy konstytucyjnej ówczesny prezydent Lech Wałęsa przedstawił nową wizję systemu kierowania i dowodzenia siłami zbrojnymi, zawartą w kolejnym dokumencie określającym politykę bezpieczeństwa oraz strategię obronną Polski, opracowanym przez Biuro Bezpieczeństwa Narodowego, a podpisanym 2 listopada 1992 r. (niepublikowany). Wskazano w nim, że zasadnicze funkcje w systemie kierowania obronnością państwa w czasie pokoju powinna być zawarte w Konstytucji. Ich realizacja powinna spoczywać w rękach prezydenta Rzeczypospolitej, prezesa Rady Ministrów i samej Rady Ministrów. Obowiązek kierowania obronnością spoczywać powinien na wszystkich organach władzy i administracji rządowej i samorządowej, stosownie do posiadanych kompetencji i wynikających z nich zadań określonych w Konstytucji i innych aktach prawnych.

W czasie pokoju prezydent miał koordynować wypracowywanie strategii obronnej państwa oraz ustalać główne kierunki rozwoju armii. Kierowanie przygotowaniami obronnymi spoczywać miało w ręku prezesa Rady Ministrów, który miałby realizować wynikające stąd zadania za pośrednictwem ministrów, przede wszystkim ministrów obrony narodowej i spraw wewnętrznych oraz wojewodów i innych organów administracji publicznej. Przebieg przygotowań obronnych pozostawiać miał pod kontrolą głowy państwa za pośrednictwem Biura Bezpieczeństwa Narodowego.

Prezydent i rząd były również głównymi ośrodkami decyzyjnymi na wypadek uruchomienia wojennego systemu kierowania państwem. Dowodzenie obroną państwa należeć miało do naczelnego dowódcy sił zbrojnych, powoływanego przez sejm, ale podległego bezpośrednio prezydentowi. Na czas wojny powoływany miał być sztab wojenny głowy państwa. W przypadku zagrożenia wojennego i wojny premier nadal miał kierować pracami rządu, wojewodów i innych organów administracji państwowej odpowiedzialnych za funkcjonowanie wszystkich pozamilitarnych struktur państwa. Najważniejszymi zadaniami administracji rządowej miało być organizowanie wsparcia, zaopatrzenia i obsługi sił zbrojnych przez sektor cywilny oraz ochrona ludności przed skutkami działań wojennych. 
Warto w tym miejscu zwrócić uwagę na niespójność w nazewnictwie głównodowodzącego pojawiającą się w najważniejszych aktach dotyczących obronności. Obowiązująca w chwili podpisywania omawianej strategii „mała konstytucja” posługiwała się pojęciem „naczelnego wodza”, natomiast strategia pojęciem „naczelnego dowódcy sił zbrojnych"5. Założenia polskiej polityki bezpieczeństwa oraz Strategia obronna były pierwszymi dokumentami tej rangi od czasu odzyskania pełnej suwerenności przez Polskę w 1989 r., w którym opisano całościową koncepcję systemu kierowania i dowodzenia siłami zbrojnymi (Kajetanowicz, 2011, s. 244 i n.).

Lata dziewięćdziesiąte ubiegłego wieku przyniosły zasadniczą zmianę otoczenia bezpieczeństwa Polski. Rozpad bloku wschodniego, zakończenie zimnej wojny, aspiracje do uczestnictwa naszego kraju w międzynarodowych strukturach państw demokratycznych oraz proces budowania demokratycznego państwa prawnego stworzyły nową jakość w wymiarze bezpieczeństwa zewnętrznego i wewnętrznego. Wymagało to świeżego spojrzenia na kwestię ukształtowania systemu kierowania i dowodzenia siłami zbrojnymi. Zbiegło się to z pracami zmierzającymi do uchwalenia demokratycznej konstytucji Rzeczypospolitej. Powołana w 1992 r. Komisja Konstytucyjna Zgromadzenia Narodowego miała za zadanie przedstawienie jednolitego tekstu nowej polskiej konstytucji do uchwalenia przez Zgromadzenie Narodowe oraz przyjęcia przez naród w drodze referendum (Ustawa Konstytucyjna z dnia 23 kwietnia 1992 r. o trybie przygotowania i uchwalenia Konstytucji Rzeczypospolitej Polskiej). W Komisji Konstytucyjnej złożono 7 projektów konstytucyjnych, odnoszących się do kwestii ustroju państwa, a w konsekwencji budowania systemu kierowania i dowodzenia siłami zbrojnymi. Przedstawione projekty różniły się, nierzadko bardzo, szczegółowością rozwiązań.

Senacki projekt konstytucji bardzo lakonicznie wypowiadał się na temat kompetencji prezydenta. Stwierdzał jedynie, że głowa państwa jest najwyższym przedstawicielem państwa i stoi na czele władzy wykonawczej. Był też zwierzchnikiem sił zbrojnych. Sprawom obronnym oraz bezpieczeństwu zewnętrznemu i wewnętrznemu poświęcono cały rozdział. O użyciu wojska poza granicami kraju decydowały w drodze uchwał obie izby parlamentu. Prezydent mógł podjąć odpowiednie postanowienie tylko wówczas, gdyby zwłoka w oczekiwaniu na decyzję sejmu mogła spowodować poważne niebezpieczeństwo dla państwa, ale musiał zasięgnąć w tym względzie opinii rządu. Prezydent mógł zdecydować również o użyciu wojska wewnątrz kraju, gdyby zostały podjęte działania zmierzające do

${ }^{5}$ Bez wątpienia pierwsze odwoływało się do polskiej tradycji, w której wojskami dowodził naczelny wódz. Ostatecznie tytuł ten nie przyjął się i zaczęto stosować drugi tytuł. 
obalenia ustroju konstytucyjnego Rzeczypospolitej albo w przypadku poważnych zamieszek z użyciem broni lub ogłoszenia stanu wojennego bądź stanu wyjątkowego, o ile użycie sił policyjnych byłoby niewystarczające. I w końcu prezydent powoływał i odwoływał generalnego inspektora sił zbrojnych, który na wypadek wojny przewidziany był na naczelnego wodza ${ }^{6}$. Zawarta w senackim projekcie koncepcja systemu kierowania i dowodzenia siłami zbrojnymi do pewnego stopnia zbieżna była z modelem zapisanym w strategii obronnej z 1992 r. Nie brakowało jednak w niej wielu reminiscencji z okresu II Rzeczypospolitej, które nie przystawały już do istniejącej rzeczywistości. Kreowano nowe stanowiska, pomijając całkowitym milczeniem już istniejące, jak chociażby szefa Sztabu Generalnego.

Projekt złożony przez Sojusz Lewicy Demokratycznej znacznie bardziej szczegółowo regulował kwestie związane z określeniem ról organów państwa w sferze obronności. Najwyższym zwierzchnikiem sił zbrojnych ustanawiano prezydenta Rzeczypospolitej. Swoje obowiązki w tym zakresie wykonywał w czasie pokoju za pośrednictwem ministra obrony narodowej i szefa Sztabu Generalnego. Na czas wojny prezydent miał mianować naczelnego wodza. Szafa Sztabu Generalnego prezydent mianował na wniosek prezesa Rady Ministrów, natomiast na wniosek ministra obrony narodowej powoływał zastępców szafa Sztabu Generalnego, dowódców rodzajów sił zbrojnych oraz dowódców okręgów wojskowych. Szczegóły zakresu uprawnień prezydenta, wynikające z konstytucji, miały zostać określone w specjalnej ustawie organicznej. W niej miały być również zawarte zasady współdziałania ministra obrony narodowej i szefa Sztabu Generalnego. Propozycje lewicy wyraźnie rozdzielały funkcje administracyjne w wojsku od spraw dowódczych. Te pierwsze znajdować się miały w gestii ministra, a dowodzenie miało być domeną szefa Sztabu Generalnego 7 .

W podobny sposób kwestię zwierzchniej władzy prezydenta nad siłami zbrojnymi ujęto w projekcie Lecha Wałęsy. Stwierdzano w nim, że sprawuje on zwierzchnictwo nad siłami zbrojnymi. Ponadto do osobistych prerogatyw głowy państwa zaliczono prawo mianowania i zwalniania szefa Sztabu Generalnego Wojska Polskiego oraz naczelnego wodza, na wypadek wojny. W odrębnym rozdziale zatytułowanym „Siły Zbrojne” jedynie powtarzano wcześniejsze postanowienia. Prezydenta określano jako najwyższego zwierzchnika sił zbrojnych. Potwierdzano osobiste prawo prezydenta do mianowania i zwalniania szefa Sztabu Generalnego. Natomiast na wniosek ministra obrony narodowej, zaopiniowany przez szefa

${ }^{6}$ Projekt senacki został przygotowany przez Komisję Konstytucyjną Senatu I kadencji w latach 1989-1991 (Chruściak, 1993, s. 3 i n.).

7 Projekt Sojuszu Lewicy Demokratycznej złożony przez parlamentarzystów tej partii 28 kwietnia 1993 r. w Komisji Konstytucyjnej Zgromadzenia Narodowego (Chruściak, 1993, s. 23 i n.). 
Sztabu Generalnego, miał mianować i zwalniać zastępców szefa Sztabu Generalnego, dowódców rodzajów sił zbrojnych oraz dowódców okręgów wojskowych. Przewidywano również powołanie Komitetu Obrony Rzeczypospolitej ${ }^{8}$. Zabrakło jednak bliższego określenia charakteru tego organu. Miała to uczynić odrębna ustawa'.

Projekt konstytucyjny Unii Demokratycznej w sposób zbliżony do wcześniej przedstawionych projektów regulował kwestię zwierzchnictwa, choć odbierano $\mathrm{w}$ nim prezydentowi prerogatywę w postaci samodzielnego powoływania szefa Sztabu Generalnego. Ta nominacja miała odbywać się w porozumieniu z ministrem obrony narodowej. Ale już mianowania dalszych dowódców odbywać się miały według tego samego trybu. Ciekawe, że pozostawiano głowie państwa prerogatywę w zakresie powoływania naczelnego wodza ${ }^{10}$. Interesujące było też, że ani projekt prezydenta Wałęsy, ani projekt Unii Demokratycznej nie podejmowały wątku wykonywania przez prezydenta uprawnień zwierzchnich za pośrednictwem ministra obrony narodowej.

Dla ludowców z Polskiego Stronnictwa Ludowego prezydent wskazywany był jako najwyższy przedstawiciel państwa w stosunkach wewnętrznych i zewnętrznych. Jednocześnie ustanawiano go strażnikiem Konstytucji oraz suwerenności i bezpieczeństwa państwa, nienaruszalności i niepodzielności jego terytorium. Wśród przynależnych mu kompetencji wymienione zostało zwierzchnictwo nad siłami zbrojnymi, choć zabrakło bliższego określenia, na czym miałoby ono polegać. Do tego akty prezydenta związane z jej wykonywaniem wymagały kontrasygnaty premiera. Poza tym projekt niewiele mówił o wpływie głowy państwa na system kierowania i dowodzenia siłami zbrojnymi. Stwierdzano w nim jedynie, że prezydent, na czas wojny, może wnioskować do Sejmu o mianowanie naczelnego wodza. Sam mógł powołać naczelnego wodza tylko wówczas, gdy parlament nie mógł się zebrać. Projekt PSL nic nie mówił o sposobie sprawowania zwierzchnictwa w czasie pokoju ${ }^{11}$.

${ }^{8}$ Nawiązywano w ten sposób do tradycji przedwojennego polskiego konstytucjonalizmu. Konstytucja marcowa z 1921 r. przewidywała powołanie Komitetu Obrony Państwa, natomiast przepisy Konstytucji kwietniowej z 1935 r. przewidywały utworzenie Komitetu Obrony Rzeczypospolitej.

9 Kancelaria prezydenta Lecha Wałęsy złożyła projekt konstytucyjny w jego imieniu 30 kwietnia 1993 r. (Chruściak, 1993, s. 68 i n.).

${ }^{10}$ Parlamentarzyści Unii Demokratycznej złożyli projekt konstytucji w Komisji Konstytucyjnej Zgromadzenia Narodowego 29 kwietnia 1993 r. (Chruściak, 1993, s. 41 i n.).

${ }^{11}$ Projekt ludowców zaprezentowany przez parlamentarzystów Polskiego Stronnictwa Ludowego i Unii Pracy został złożony w Komisji Konstytucyjnej Zgromadzenia Narodowego w dniu 30 kwietnia 1993 r. (Chruściak, 1993, s. 53 i n.). 
Konfederacja Polski Niepodległej przygotowała eklektyczny projekt konstytucji, nawiązujący swoimi rozwiązaniami ustrojowymi w wielu miejscach do tradycji I i II Rzeczypospolitej, jak chociażby wówczas, gdy prezydent Rzeczypospolitej określony został jako reprezentant państwa w stosunkach zewnętrznych i wewnętrznych. Odpowiedzialny był za kierowanie działalnością państwa, przewodniczenie Sejmowi i strzeżenie przestrzegania Konstytucji. Do niego miało należeć określanie kierunków m.in. polityki obronnej państwa oraz pełnił funkcję naczelnego wodza sił zbrojnych. Do prerogatyw prezydenckich zaliczono mianowanie i zwalnianie generalnego inspektora sił zbrojnych w czasie pokoju oraz naczelnego dowódcy sił zbrojnych w czasie wojny, a także wyznaczanie swego następcy w czasie wojny. Do niego należało podjęcie decyzji o użyciu wojsk do obrony państwa. Prezydent, w czasie pokoju, wykonywał swoje obowiązki wynikające ze zwierzchnictwa nad siłami zbrojnymi za pośrednictwem ministra obrony narodowej, natomiast w czasie zagrożenia wojennego i wojny za pośrednictwem naczelnego dowódcy. Za przygotowanie państwa do obrony odpowiedzialny był generalny inspektor sił zbrojnych. Prezydent za pośrednictwem dekretów miał regulować kwestie wynikające ze zwierzchnictwa nad armią, w szczególności w tej formie miały być uregulowane sprawy związane z organizacją naczelnych władz wojskowych, w tym sposób kontrasygnowania aktów wydawanych przez prezydenta jako naczelnego wodza. Przepis ten łudząco przypominał rozwiązania zawarte w Konstytucji kwietniowej z 1935 r. Posunięto się nawet do użycia archaicznego już wówczas języka, gdy pisano o kompucie sił zbrojnych. Przedstawione rozwiązania nazbyt odbiegały od regulacji charakterystycznych dla nowoczesnego państwa ${ }^{12}$.

Ostatni zgłoszony projekt autorstwa Porozumienia Centrum sytuował prezydenta Rzeczypospolitej jako najwyższego przedstawiciela państwa oraz stojącego na czele władzy wykonawczej. Wśród przyznawanych mu uprawnień było zwierzchnictwo nad siłami zbrojnymi. Bliższe wskazanie, na czym miałoby ono polegać, zostało zawarte w odrębnym rozdziale poświęconym sprawom obronności i stanom nadzwyczajnym. Na podstawie zamieszczonych tam przepisów prezydent powoływał i odwoływał generalnego inspektora sił zbrojnych, decydował, za zgodą parlamentu, o użyciu wojsk poza granicami państwa. Postanawiał też o użyciu sił zbrojnych wewnątrz kraju na wniosek rządu, w ściśle określonych przypadkach (stan wojenny, stan wyjątkowy, rozruchy z użyciem broni), gdyby użycie sił policyjnych okazało się niewystarczające ${ }^{13}$.

${ }^{12}$ Parlamentarzyści Konfederacji Polski Niepodległej złożyli projekt Konstytucji w dniu 30 kwietnia 1993 r. (Chruściak, 1993, s. 81 i n.).

13 Posłowie i senatorowie należący do Porozumienia Centrum złożyli w Zgromadzeniu Narodowym swój projekt Konstytucji w dniu 30 kwietnia 1993 r. (Chruściak, 1993, s. 98 i n.). 
Dokonując analizy projektów konstytucyjnych, które stały się podstawą skonstruowania aktualnie obowiązującej w Polsce ustawy zasadniczej, można odnieść wrażenie, że ich autorzy nie do końca wykorzystali szansę, by napisać akt normatywny statuujący ramy dla nowoczesnego państwa. Odwoływanie się w wielu projektach do rozwiązań z okresu II Rzeczypospolitej, a nawet czasów przedrozbiorowych wskazuje, że politycy kierowali się raczej sentymentalną tęsknotą za dawnymi formami polskiej państwowości aniżeli dążeniem do wskazania wizji państwa na miarę XXI wieku, opartej na nowoczesnej myśli politycznej. Należy zauważyć, że w niektórych projektach znalazły się odniesienia do obowiązującej Strategii Obronnej Polski.

Trwające blisko cztery lata prace Komisji Konstytucyjnej Zgromadzenia Narodowego zakończyły się w 1997 r. uchwaleniem przez parlament projektu Konstytucji Rzeczypospolitej Polskiej, przyjętej następnie w drodze referendum ogólnonarodowego. Nowa ustawa zasadnicza określiła prezydenta Rzeczypospolitej, w sprawach obronności i bezpieczeństwa, jako gwaranta suwerenności i bezpieczeństwa państwa oraz nienaruszalności i niepodzielności jego terytorium. Konsekwencją przyjętej konstrukcji było złożenie w ręce głowy państwa najwyższego zwierzchnictwa nad siłami zbrojnymi, ale o wyłącznie cywilnym charakterze. Prezydenta nie wyposażono w atrybuty naczelnego dowódcy w okresie pokoju, a tym bardziej w okresie wojny. Zatem przyznane kompetencje mają charakter dowództwa ideowego (Winczorek, 2008, s. 292 i n.; zob. też: Witkowski, 2006, s. 441 i n.). W wykonywaniu swoich zadań w zakresie zwierzchnictwa nad siłami zbrojnymi prezydent musi współpracować z premierem albo ministrem obrony narodowej. Przede wszystkim dotyczy to decyzji kreacyjnych związanych z powoływaniem i odwoływaniem szefa Sztabu Generalnego i dowódców rodzajów sił zbrojnych oraz naczelnego dowódcy sił zbrojnych na czas wojny. Należy jednak zauważyć, że kompetencje konstytucyjne prezydenta uzupełniane są kompetencjami zawartymi w ustawodawstwie zwykłym. I tak np. w ustawie o powszechnym obowiązku obrony zobligowano prezydenta m.in. do zatwierdzania strategii bezpieczeństwa narodowego, wydawania dyrektywy obronnej państwa oraz określania dnia rozpoczęcia czasu wojny i dnia jego zakończenia. Natomiast w ustawie o stanie wojennym ustawodawca wskazał, że w przypadku konieczności obrony państwa obroną tą kieruje prezydent Rzeczypospolitej we współdziałaniu z rządem. Ponadto określa stany gotowości wojska, zatwierdza plany operacyjne użycia sił zbrojnych oraz uznaje określone obszary za strefy bezpośrednich działań wojennych. $Z$ powyższego jednoznacznie wynika, że obowiązujące w naszym kraju normy wyznaczają głowie państwa znaczącą pozycję w systemie kierowania i dowodzenia siłami zbrojnymi. Wejście w życie nowej ustawy zasadniczej Rzeczy- 
pospolitej zbiegło się w czasie z rozpoczęciem rozmów akcesyjnych do $\mathrm{NATO}^{14}$. Przystąpienie do sojuszu z dniem 12 marca 1999 r. wymagało zmian w systemie kierowania i dowodzenia siłami zbrojnymi.

Wspomniane wyżej zdarzenia obligowały władze do opracowania nowego dokumentu określającego cele strategiczne w dziedzinie obronności, w tym kształt systemu kierowania i dowodzenia siłami zbrojnymi. Nową Strategię Obronną Rzeczypospolitej Polskiej podpisał premier Jerzy Buzek 23 maja 2000 r. (s. 16 i n.). Odwołując się do rozwiązań konstytucyjnych, dokument ten wskazywał na prezydenta Rzeczypospolitej i Radę Ministrów jako naczelne ograny kierowania obronnością. Rolę organów doradczych pełniły Rada Bezpieczeństwa Narodowego oraz Komitet Spraw Obronnych Rady Ministrów. W czasie pokoju sferą obronności kierował rząd, współdziałając z głową państwa. W imieniu rządu całością sił zbrojnych kierował minister obrony narodowej. Centralnym organem planowania strategicznego był Sztab Generalny Wojska Polskiego. Funkcje dowódcze w stosunku wojsk pełnili dowódcy rodzajów sił zbrojnych, odpowiadając za stan przygotowań sił zbrojnych do działań w czasie kryzysu i wojny. Ponadto dowódcy ci współpracowali z dowództwami sojuszniczymi, którym podlegać miały wy-

${ }_{14}$ Podczas spotkania ministrów spraw zagranicznych Grupy Wyszehradzkiej 5 października 1991 r. w Krakowie, w ramach szczytu tej inicjatywy politycznej, wydano oświadczenie stwierdzające, że „ministrowie wyrazili zadowolenie z dotychczasowego rozwoju kontaktów z Sojuszem i zgodzili się, że rozwój wydarzeń w Europie Środkowej i Wschodniej, jak również na Bałkanach wymaga podniesienia kontaktów ich krajów z NATO na jakościowo wyższy poziom. [...] Ministrowie Spraw Zagranicznych są zdania, że dotychczasową formułę kontaktów dyplomatycznych („diplomatic liaison”) trzeba znacznie rozszerzyć w celu stworzenia warunków dla bezpośredniego włączenia Rzeczypospolitej Polskiej, Czeskiej i Słowackiej Republiki Federacyjnej i Republiki Węgierskiej w działalność Sojuszu". Była to odpowiedź na inicjatywę sekretarza stanu USA Jamesa Bakera i ministra spraw zagranicznych RFN Hansa-Dietricha Genschera utworzenia Północnoatlantyckiej Rady Współpracy, stwarzającej państwom Europy Środkowej i Wschodniej platformy pogłębionej współpracy z NATO. W następstwie wysyłanych impulsów ówczesny sekretarz generalny NATO Manfred Wörner podczas wizyty w Warszawie w dniach 11-12 marca 1992 r. stwierdził, że „drzwi do NATO są otwarte”. Na spotkaniu z prezydentem USA Billem Clintonem w dniu 12 stycznia 1994 r. w Pradze prezydenci Polski, Czech, Słowacji i Węgier zaakceptowali Program dla Pokoju. Kilka tygodni później, 2 lutego 1994 r., premier polskiego rządu Waldemar Pawlak podpisał w Kwaterze Głównej NATO w Brukseli Dokument Ramowy Partnerstwa dla Pokoju. Podczas szczytu madryckiego NATO 8 sierpnia 1997 r. wystosowano do państw środkowoeuropejskich zaproszenie do podjęcia rozmów o przystąpieniu do NATO. Polska rozpoczęła rozmowy akcesyjne w dniu 16 września 1997 r. Dwa miesiące później, 16 grudnia 1997 r., ministrowie spraw zagranicznych NATO podpisali Protokoły Akcesyjne dla Polski, Czech, Słowacji i Węgier. Niemal rok później, 29 stycznia 1999 r., ówczesny sekretarz generalny NATO Javier Solana wystosował formalne zaproszenie do przystąpienia do Traktatu waszyngtońskiego. Ratyfikacji traktatu dokonał Prezydent Rzeczypospolitej w dniu 18 lutego 1999 r. Dokumenty ratyfikacyjne zostały złożone rządowi USA w dniu 12 marca 1999 r. Od tego momentu nasz kraj stał się stroną Paktu Północnoatlantyckiego. 
dzielone wojska, a po wydzieleniu odpowiadali za wszechstronne zabezpieczenie. Powyższe zasady obowiązywały także w czasie kryzysu. Wojska wydzielone do działań w ramach reagowania kryzysowego poza granicami kraju podlegały dowódcom operacyjnym takich kontyngentów.

W warunkach wojennych kierowanie siłami zbrojnymi pozostawało w ręku prezydenta Rzeczypospolitej, prezesa Rady Ministrów oraz ministra obrony narodowej. Dowodzenie wojskami przechodziło w ręce naczelnego dowódcy sił zbrojnych, mianowanego przez prezydenta na wniosek premiera. Za wojenne rozwinięcie wojsk odpowiadali dowódcy okręgów wojskowych wchodzący w skład Wojennego Systemu Dowodzenia, budowanego już w okresie pokoju. Proces dowodzenia realizowany był w systemie narodowym i sojuszniczym. Całością sił zbrojnych będących w narodowym podporządkowaniu dowodził naczelny dowódca sił zbrojnych. Dowodzenie narodowe obejmowało wszystkie wojska niewydzielone do zgrupowań sojuszniczych oraz pozaoperacyjnie wojska przekazane dowództwom sojuszniczym. W tym zakresie dowództwo narodowe odpowiadało za szkolenie rezerw, uzupełnienia oraz wsparcie logistyczne przekazanych kontyngentów, a także zapewniało warunki dla przyjęcia sił wzmocnienia w ramach Host Nation Support (HNS). Wojska wydzielone przechodziły pod wielonarodowe dowództwo sojusznicze. Wpływ władz polskich na te wojska odbywał się za pośrednictwem polityczno-wojskowych organów kierowania Paktu Północnoatlantyckiego.

Zanim doszło do uchwalenia nowej ustawy zasadniczej, minister obrony narodowej swoim zarządzeniem określił kierownicze organy wykonawcze, dzięki którym Sztab Generalny integrował wszystkie instytucje centralne wojska oraz stawał się organem skupiającym i koordynującym funkcjonowanie wszystkich struktur odpowiedzialnych za przygotowanie sił zbrojnych do wypełniania konstytucyjnych zadań. W tych warunkach szef Sztabu Generalnego stawał się organem dowodzenia całości Sił Zbrojnych RP (Zarządzenie nr PF 1/MON z dnia 22 października 1992 r. w sprawie określenia kierowniczych organów wykonawczych oraz przeformowania Ministerstwa Obrony Narodowej). Potwierdzenie przyjętych rozwiązań znalazło się w uchwalonej przez sejm ustawie o urzędzie Ministra Obrony Narodowej, która sytuowała szefa resortu jako naczelny organ administracji państwowej w dziedzinie obronności państwa. Natomiast dowodzenie wojskami w imieniu ministra w czasie pokoju powierzone zostało szefowi Sztabu Generalnego, którego jednocześnie określono jako najwyższego pod względem pełnionej funkcji żołnierza w czynnej służbie wojskowej (Ustawa z dnia 14 grudnia 1995 r. o urzędzie Ministra Obrony Narodowej, art. 7 ust. 2) ${ }^{15}$.

15 W nowelizacji ustawy z dnia 21 czerwca 2013 r. przepis ten został uchylony. 
Nowa ustawa zasadnicza dokonała, obok określenia najwyższych organów kierowania i dowodzenia sił zbrojnych, również konstytucjonalizacji pośredniego szczebla dowodzenia pomiędzy szefem Sztabu Generalnego a dowódcami okręgów wojskowych. Był nim poziom dowódców rodzajów sił zbrojnych, choć do formowania odpowiednich dowództw przystąpiono na długo przed ostatecznym uchwaleniem konstytucji. Dowództwo Marynarki Wojennej zostało sformowane jeszcze w lipcu 1945 roku. W okresie PRL przechodziło różne reorganizacje. Po przystąpieniu do NATO przeprowadzane reorganizacje zawierały się w procesie dostosowywania struktur polskich sił zbrojnych do struktur Paktu Północnoatlantyckiego. Natomiast w 1989 r. utworzono Dowództwo Wojsk Lotniczych. W roku następnym połączono je z Dowództwem Wojsk Obrony Powietrznej Kraju, tworząc Dowództwo Wojsk Lotniczych i Obrony Powietrznej, które z dniem 1 lipca 2004 r. zostało przekształcone na Dowództwo Sił Powietrznych. Dowództwo Wojsk Lądowych zostało uformowane na bazie funkcji dowódczych przejętych z likwidowanych okręgów wojskowych (Rozporządzenie Rady Ministrów z dnia 3 września 1998 r. w sprawie utworzenia okręgów wojskowych oraz określenia ich siedzib i terytorialnego działania) ${ }^{16}$. Ustawowe określenie zakresu działania dowódców rodzajów wojsk nastąpiło dopiero w 2007 r. (Ustawa z dnia 24 maja 2007 r. o zmianie ustawy o powszechnym obowiązku obrony Rzeczypospolitej Polskiej oraz o zmianie niektórych innych ustaw). Do ich zadań należało: dowodzenie związkami organizacyjnymi i jednostkami wojskowymi należącymi do podległych im rodzajów wojsk, planowanie i realizacja mobilizacyjnego i operacyjnego rozwinięcia podległych im rodzajów wojsk, szkolenie podległych związków organizacyjnych i jednostek wojskowych, przygotowanie sił i środków podległych im rodzajów wojsk do działań bojowych oraz w sytuacjach przewidzianych w ustawach i ratyfikowanych umowach międzynarodowych, współdziałanie w zakresie ochrony granicy państwowej. Ponadto Dowódca Marynarki Wojennej przewodniczył Radzie SAR, odpowiedzialnej za sprawy ratownictwa morskiego ${ }^{17}$.

${ }^{16}$ Nowe utworzone wówczas okręgi wojskowe powstały wyłącznie na potrzeby administracji wojskowej.

17 Szczegółowe określenie obowiązków dowództw rodzajów sił zbrojnych zawierały załączniki nr 1 do zarządzeń: Zarządzenia nr Z-4/MON Ministra Obrony Narodowej z dnia 15 lutego 2008 r. w sprawie szczegółowego zakresu działania, struktury organizacyjnej oraz siedziby Dowództwa Wojsk Lądowych, Dz. Urz. MON z 2008 r., nr 7, poz. 67; Zarządzenia nr Z-5/MON Ministra Obrony Narodowej z dnia 15 lutego 2008 r. w sprawie szczegółowego zakresu działania, struktury organizacyjnej oraz siedziby Dowództwa Marynarki Wojennej, Dz. Urz. MON z 2008 r., nr 7, poz. 68; Zarządzenia nr Z-5/MON Ministra Obrony Narodowej z dnia 15 lutego 2008 r. w sprawie szczegółowego zakresu działania, struktury organizacyjnej oraz siedziby Dowództwa Wojsk Lądowych, Dz. Urz. MON z 2008 r., nr 7, poz. 67; Zarządzenia nr Z-6/MON Ministra Obrony Narodowej z dnia 
W tym samym roku niepublikowaną decyzją ministra obrony narodowej z dnia 22 października 2003 r. utworzono Dowództwo Operacyjne. Do jego zadań należało: dowodzenie polskimi kontyngentami wojskowymi w misjach i operacjach, planowanie użycia sił $\mathrm{w}$ operacjach kryzysowych, militarnych i niemilitarnych, szkolenie i zgrywanie dowództw oraz sił wydzielonych komponentów Wojsk Lądowych, Sił Powietrznych i Marynarki Wojennej w operacjach połączonych, monitorowanie gotowości narodowych komponentów wydzielonych Sił Odpowiedzialności NATO. W roku 2007 nastąpiło ustawowe określenie zadań przy jednoczesnym przemianowaniu na Dowództwo Operacyjne Sił Zbrojnych. Zaliczono do nich: planowanie operacyjne i dowodzenie operacyjne częścią Sił Zbrojnych, wydzieloną z Wojsk Lądowych, Sił Powietrznych oraz Marynarki Wojennej i przekazaną w jego podporządkowanie decyzją ministra obrony narodowej dla przeprowadzenia operacji, wykonywanie zadań ministra obrony narodowej w zakresie ochrony granicy państwowej w przestrzeni powietrznej Rzeczypospolitej Polskiej oraz przewodniczenie Radzie SAR, o której mowa w art. 47 ustawy z dnia 9 listopada 2000 r. o bezpieczeństwie morskim (Dz.U. z 2006 r., Nr 99, poz. 693), określanie wymagań w zakresie zdolności bojowej dla związków organizacyjnych i jednostek wojskowych przewidywanych do wydzielenia w jego podporządkowanie, szkolenie organów dowodzenia operacyjnego Sil Zbrojnych, a także ich zgrywanie z dowództwami związków organizacyjnych i jednostek wojskowych przewidywanych do wydzielenia w jego podporządkowanie (Ustawa z dnia 24 maja 2007 r. o zmianie ustawy o powszechnym obowiązku obrony Rzeczypospolitej Polskiej oraz o zmianie niektórych innych ustaw).

Tą samą nowelizacją ustawową powołano do życia Dowództwo Wojsk Specjalnych, którego zadaniem było dowodzenie związkami organizacyjnymi i jednostkami wojskowymi Wojsk Specjalnych, planowanie oraz realizacja mobilizacyjnego i operacyjnego rozwinięcia oraz użycia Wojsk Specjalnych, szkolenie podległych związków organizacyjnych i jednostek wojskowych, a także przygotowanie sił i środków Wojsk Specjalnych do działań bojowych oraz w sytuacjach przewidzianych w ustawach i ratyfikowanych umowach międzynarodowych (Ustawa z dnia 24 maja 2007 r. o zmianie ustawy o powszechnym obowiązku obrony Rzeczypospolitej Polskiej oraz o zmianie niektórych innych ustaw). Wojska Specjalne uzyskały status odrębnego rodzaju sił zbrojnych, a ich dowódca rangę dowódcy rodzaju sił zbrojnych. Dowódca Wojsk Specjalnych otrzymał samodzielność, nie został bowiem podporządkowany Dowódcy Operacyjnemu Sił Zbrojnych, w odróżnieniu

15 lutego 2008 r. w sprawie szczegółowego zakresu działania, struktury organizacyjnej oraz siedziby Dowództwa Wojsk Lądowych, Dz. Urz. MON z 2008 r., nr 7, poz. 69. 
od pozostałych dowódców rodzajów sił zbrojnych. Jednakże samodzielność tę utracił 1 stycznia 2014 r. na mocy ustawy reformującej system kierowania i dowodzenia siłami zbrojnymi (Ustawa z dnia 21 czerwca 2013 r. o zmianie ustawy o urzędzie Ministra Obrony Narodowej oraz niektórych innych ustaw). Dotychczasowe Dowództwo Wojsk Specjalnych zostało podzielone na Inspektorat Wojsk Specjalnych, umiejscowiony w strukturach Dowództwa Generalnego Rodzajów Sił Zbrojnych, oraz Dowództwo Sił Specjalnych, ale podległe Dowództwu Generalnemu Rodzajów Sił Zbrojnych. Po 10 dniach istnienia Dowództwo Sił Specjalnych zostało przekształcone w Centrum Operacji Specjalnych - Dowództwo Komponentu Wojsk Specjalnych i podporządkowane Dowództwu Operacyjnemu Rodzajów Sił Zbrojnych. Tym samym dokonano rozdzielenia zadań związanych ze szkoleniem i wyposażeniem oddziałów specjalnych od zadań operacyjnych. Pozbawienie wojsk specjalnych autonomii i spójności w zakresie dowodzenia, szkolenia i wyposażenia zostało krytycznie oceniona zarówno przez wojskowych, jak i specjalistów.

Nieco wcześniej minister obrony narodowej decyzją nr Z-74/Org./P1 z dnia 6 października 2006 r. ustanowił Inspektorat Wsparcia Sił Zbrojnych, którego zadaniem było planowanie pełnego zabezpieczenia logistycznego funkcjonowania wojska. Ustawowe uregulowanie pozycji Inspektoratu nastąpiło we wspomnianej już nowelizacji ustawy obronnej z 2007 roku. Określone zostały w niej zadania szefa Inspektoratu, do których należały: organizowanie i kierowanie systemem wsparcia logistycznego sił zbrojnych, w tym zabezpieczeniem logistycznym jednostek wojskowych użytych lub przebywających poza granicami kraju, kierowanie procesem planowania i realizacji zadań wynikających z pełnienia funkcji państwa gospodarza (HNS) i państwa wysyłającego, zarządzanie obroną terytorialną, wydzielonymi siłami inżynierii wojskowej i obrony przed bronią masowego rażenia oraz kierowanie terenowymi organami wykonawczymi ministra obrony narodowej w sprawach operacyjno-obronnych i rządowej administracji niezespolonej ${ }^{18}$. W wykonaniu ustawy z dniem 1 stycznia 2012 r. Inspektorat przejął obowiązki dotychczas wykonywane przez Pomorski i Śląski Okręgi Wojskowe na podstawie niepublikowanej decyzji ministra obrony narodowej z dnia 28 grudnia 2011 roku.

Miesiąc wcześniej, 8 listopada 2011 r., ówczesny prezydent RP, zwierzchnik sił zbrojnych Bronisław Komorowski wydał postanowienie określające główne kierunki rozwoju wojska oraz jego przygotowań do obrony państwa na lata 2013-2022 (M.P. z 2011 r., nr 103, poz. 1030). W kolejnych latach podjęte zostały

${ }^{18}$ Ustawą z dnia 3 grudnia 2010 r. o zmianie ustawy o wojewodzie i administracji rządowej w województwie oraz o zmianie niektórych innych ustaw (Dz.U. z 2011 r., $\mathrm{Nr}$ 22, poz. 114) rozformowano okręgi wojskowe i zlikwidowano stanowiska ich dowódców. 
prace nad opracowaniem kompleksowej reformy systemu kierowania i dowodzenia siłami zbrojnymi w naszym kraju. Głównym autorem jej założeń był gen. Stanisław Koziej, ówczesny szef Biura Bezpieczeństwa Narodowego. W jego przekonaniu uniwersalny model kierowania i dowodzenia powinien być zbudowany $\mathrm{z}$ trzech pionów obejmujących instytucję planowania strategicznego, instytucję dowodzenia ogólnego i instytucję dowodzenia operacyjnego. Instytucji dowodzenia ogólnego powinna być podporządkowana w pełni całość związków taktycznych i operacyjnych sił zbrojnych. Z nich miało następować wydzielanie sił do operacji, które na ten czas podporządkowywane powinny być instytucji dowodzenia operacyjnego. Przy tym siły te nadal pozostawałyby podporządkowane instytucji dowodzenia ogólnego w sferze pozaoperacyjnej. Wszystkie trzy piony powinny podlegać bezpośrednio jednemu decydentowi. Model ten oparty był na rozwiązaniach obowiązujących w armii Stanów Zjednoczonych oraz w strukturach dowódczych Paktu Północnoatlantyckiego (Koziej, 2013).

Projektowany system kierowania i dowodzenia siłami zbrojnymi miał w racjonalny sposób dokonać konsolidacji strategicznego systemu dowodzenia wokół jego trzech podstawowych funkcji sprzężonych z kierowaniem politycznym, wraz z ujednoliceniem systemu na czas pokoju, kryzysu i wojny. Przesłankami uzasadniającymi przyjęcie takiej konstrukcji były zachwiane proporcje pomiędzy liczebnością wojska a liczbą dowództw centralnych, powielanie wielu podobnych funkcji centralnych generujących zbędne koszty i wreszcie utrudnione szkolenie w systemie ,joint”. Zwracano również uwagę na fakt, że dotychczasowe ustawodawstwo, przelewając uprawnienia dowódcze na szefa Sztabu Generalnego, działającego w imieniu szefa MON, „ubezwłasnowolnia” tego ostatniego. A ponadto bez upoważnienia konstytucyjnego hierarchizowało konstytucyjne organy dowódcze, ustanawiając nadrzędność jednego nad pozostałymi i oddzielając je od władzy cywilnej. Brakowało także ujednolicenia systemu dowodzenia na czas pokoju i wojny. Przede wszystkim przepisy milczały na temat organu przygotowującego się w czasie „P” do roli konstytucyjnego organu naczelnego dowódcy sił zbrojnych. System wojenny, w tym Naczelne Dowództwo, miał organizować się dopiero w stanie wojennym. Podobnie Sztab Generalny byłby reorganizowany na potrzeby wojenne dopiero w czasie wojny (Koziej, 2013).

Sejm dokonał zmiany systemu kierowania i dowodzenia siłami zbrojnymi, uchwalając 21 czerwca 2013 r. nowelizację szeregu ustaw obronnych. W myśl nowych regulacji prezydent Rzeczypospolitej, jako zwierzchnik sił zbrojnych, wykonuje swoje obowiązki w czasie pokoju za pośrednictwem ministra, a w czasie wojny za pośrednictwem naczelnego dowódcy sił zbrojnych. Szef Sztabu Generalnego stał się podległym szefa resortu, a Sztab Generalny włączony został w struktury 
Ministerstwa. Zasadniczej zmianie ulegała funkcja szefa Sztabu Generalnego. Tracił bowiem całkowicie funkcje dowódcze, a stawał się organem planistycznym i doradczym ministra. Likwidacji uległy wszystkie dotychczasowe dowództwa rodzajów sił zbrojnych, a w to miejsce utworzone zostały dwa nowe: Dowództwo Generalne Rodzajów Sił Zbrojnych oraz Dowództwo Operacyjne Rodzajów Sił Zbrojnych. Dowódca Generalny dowodzi jednostkami wojskowymi i związkami organizacyjnymi sił zbrojnych, które nie zostały bezpośrednio podporządkowane ministrowi obrony narodowej lub innym organom i podmiotom albo Dowódcy Operacyjnemu. Natomiast Dowódca Operacyjny dowodzi częścią Sił Zbrojnych podporządkowanych mu na podstawie decyzji szefa resortu obrony (Ustawa z dnia 21 czerwca 2013 r. o zmianie ustawy o urzędzie Ministra Obrony Narodowej oraz niektórych innych ustaw).

Zbudowanie racjonalnego systemu kierowania i dowodzenia siłami zbrojnymi jest bez wątpienia niezwykle istotne z punktu widzenia sprawności obronnej polskiej armii i systemu obronnego Polski. Zdaniem Mariana Moraczewskiego jest to tylko wstęp do reformy całego systemu wojskowego, uwzględniającej rysujące się zagrożenia i najbardziej prawdopodobne scenariusze wojny, zarówno w układzie sojuszniczym, jak i osamotnionym. Rodzi się także niepokój, czy na linii szef Sztabu Generalnego - Dowódca Generalny - Dowódca Operacyjny nie będzie dochodzić do spięć, a ponadto czy cywilny minister obrony stał się wojskowym przełożonym żołnierzy, czy jest tylko przełożonym politycznym i administracyjnym (Moraczewski, 2013, s. 12 i n.). Należy zauważyć, że przyjęte rozwiązania normatywne nie do końca są precyzyjne, jak chociażby w odniesieniu do naczelnego dowódcy sił zbrojnych. W przyjętych regulacjach pojawił się co prawda przepis mówiący o przygotowywaniu się osoby wskazanej w czasie pokoju do objęcia stanowiska naczelnego dowódcy na czas wojny, ale w tym samym przepisie mowa jest o tym, że prezydent stanowisko to może powierzyć zupełnie innej osobie, a zatem nieprzygotowanej (Ustawa z dnia 21 listopada 1967 r. o powszechnym obowiązku obrony Rzeczypospolitej Polskiej, art. 5a). Naturalnym kandydatem do objęcia stanowiska naczelnego dowódcy sił zbrojnych był dowódca operacyjny rodzajów sił zbrojnych. Jednakże ostatnio postanowieniem z 5 maja 2017 r. prezydent RP na to stanowisko wskazał aktualnego szefa Sztabu Generalnego, który w świetle obowiązujących przepisów nie posiada żadnych uprawnień dowódczych (Postanowienie Prezydenta Rzeczypospolitej Polskiej z dnia 5 maja 2017 r. o wskazaniu osoby przewidzianej do mianowania na stanowisko Naczelnego Dowódcy Sił Zbrojnych). Przywołany tutaj przykład braku jednoznaczności w systemie kierowania i dowodzenia siłami zbrojnymi stanowi poważne zagrożenie dla stabilności systemu bezpieczeństwa narodowego państwa, szczególnie na wypadek wojny. 


\section{Bibliografia:}

Biuro Bezpieczeństwa Narodowego. (2013). Kierowanie bezpieczeństwem narodowym. Pobrane z: https:/www.bbn.gov.pl/pl/bezpieczenstwo-narodowe/system-bezpieczenstwa-n/kierowanie-bezpieczenst/5975, Kierowanie-bezpieczenstwem-narodowym.html.

Chruściak, R. (red.). (1993). Projekty konstytucji Rzeczypospolitej Polskiej 1993. Warszawa: Wydawnictwo Sejmowe.

Druk Sejmu Rzeczypospolitej Polskiej nr 994 z dnia 19 lipca 1991 r.

Kajetanowicz J. (2011). Strategie bezpieczeństwa Polski w drugiej połowie XX wieku. Zeszyty Naukowe Wyższej Szkoty Oficerskiej Wojsk Lądowych, 161(3), 238-248.

Kajetanowicz, J. (2013). Wojsko Polskie w systemie bezpieczeństwa państwa 1945-2010. Częstochowa: Akademia im. Jana Długosza w Częstochowie.

Kitler, W., Czuryk, M., Karpiuk, M. (red.). (2012). Aspekty prawne bezpieczeństwa narodowego. Czesść ogólna. Warszawa: Akademia Obrony Narodowej.

Konstytucja Polskiej Rzeczypospolitej Ludowej uchwalona przez Sejm Ustawodawczy w dniu 22 lipca 1952 r. (1952). Dz.U. z 1952 r., Nr 33, poz. 232.

Koziej, S. (2013). Reforma systemu kierowania i dowodzenia sitami zbrojnymi RP. Pobrane z: https:/www.bbn.gov.pl/pl/wydarzenia/4396,Reforma-systemu-kierowania-i-dowodzenia.html.

Kulisz, M. (2008). Analiza procesu planowania strategicznego bezpieczeństwa Polski w latach 1990-2007. Doctrina. Studia Społeczno-Polityczne, 5, 99-111.

Lech, L. (2016). Konstytucyjne zmagania. Pobrane z: http://przegladdziennikarski.pl/konstytucyjne-zmagania/.

Mędykowski, A., Szulc, B., Zalewski, J. (2003). Uwarunkowania polityczno-militarne i prawne zmian w działalności i strukturze organizacyjnej. W: T. Panecki, F. Puchała, J. Szostak (red.), Sztab Generalny Wojska Polskiego 1918-2003 (349-354). Warszawa: Dom Wydawniczy Bellona.

Moraczewski, M. (2013). Reforma systemu kierowania i dowodzenia Siłami Zbrojnymi. Armia, 55(3), 12-15.

Onyszkiewicz, J. (1999). Ze szczytów do NATO. Warszawa: Dom Wydawniczy Bellona.

Oświadczenie rządowe z dnia 25 maja 1993 r. w sprawie wejścia w życie Protokołu sporządzonego w Pradze dnia 1 lipca 1991 r. o utracie mocy Układu o przyjaźni, współpracy i pomocy wzajemnej, podpisanego w Warszawie dnia 14 maja 1955 r., oraz Protokołu o przedłużeniu jego obowiązywania, podpisanego w Warszawie dnia 26 kwietnia 1985 r. (1993). Dz.U. z 1993 r., Nr 61, poz. 290.

Padzik, J. (2011). Prawnoustrojowa pozycja ministra obrony narodowej w systemie organów administracji rządowej. Bezpieczeństwo Narodowe, 20, 95-104.

Piotrowski, P. (2000). Koncepcje „Frontu Polskiego” w okresie powojennym. Zeszyty Naukowe Wyższej Szkoty Oficerskiej im. T. Kościuszki, 3, 24-26.

Postanowienie Prezydenta Rzeczypospolitej Polskiej z dnia 5 maja 2017 r. o wskazaniu osoby przewidzianej do mianowania na stanowisko Naczelnego Dowódcy Sił Zbrojnych. (2017). M.P. z 2017 r., poz. 668.

Postanowienie prezydenta Rzeczypospolitej Polskiej z dnia 8 listopada 2011 r. w sprawie określenia głównych kierunków rozwoju Sił Zbrojnych Rzeczypospolitej Polskiej oraz 
ich przygotowań do obrony państwa na lata 2013-2022. (2011). M.P. z 2011 r., nr 103, poz. 1030 .

Protokół sporządzony w Pradze dnia 1 lipca 1991 r. o utracie mocy Układu o przyjaźni, współpracy i pomocy wzajemnej, podpisanego w Warszawie dnia 14 maja 1955 r., oraz Protokołu o przedłużeniu jego obowiązywania, podpisanego w Warszawie dnia 26 kwietnia 1985 r. (1991). Dz.U. z 1985 r., Nr 61, poz. 289.

Rozporządzenie Rady Ministrów z dnia 3 września 1998 r. w sprawie utworzenia okręgów wojskowych oraz określenia ich siedzib i terytorialnego działania. (1998). Dz.U. z 1998 r., Nr 120, poz. 774.

Rozporządzenie Rady Ministrów z dnia 5 czerwca 1992 r. w sprawie utworzenia okręgów wojskowych oraz określenia ich siedzib i terytorialnego zasięgu działania. (1992). Dz.U. z 1992 r., Nr 48, poz. 217.

Sprawozdanie Stenograficzne z 70 posiedzenia Sejmu Rzeczypospolitej Polskiej X Kadencji w dniach 21, 22, 23 i 24 sierpnia 1991 r. (1991). Pobrane z: http://orka2.sejm.gov.pl/ StenogramyX.nsf/0/3A7BAE215D1CDE80C1257D20002CC73D/\$file/070_000 007171.pdf.

Strategia Obronności Rzeczypospolitej Polskiej. (2000). Warszawa: Biuro Prasy i Informacji Ministerstwa Obrony Naukowej.

Uchwała Komitetu Obrony Kraju z dnia 21 lutego 1990 r. w sprawie Doktryny Obronnej Rzeczypospolitej Polskiej. (1990). M.P. z 1990 r., nr 9, poz. 66.

Uchwała Sejmu Rzeczypospolitej Polskiej z dnia 9 marca 1991 r. w sprawie terminu rozwiązania się Sejmu. (1991). M.P. z 1991 r., nr 9, poz. 63.

Ustawa Konstytucyjna z dnia 23 kwietnia 1992 r. o trybie przygotowania i uchwalenia Konstytucji Rzeczypospolitej Polskiej. (1992). Dz.U. z 1992 r., Nr 67, poz. 336.

Ustawa konstytucyjna z dnia 17 października 1992 r. o wzajemnych stosunkach między władzą ustawodawczą i wykonawczą Rzeczypospolitej Polskiej oraz o samorządzie terytorialnym. (1992). Dz.U. z 1992 r., Nr 84, poz. 426.

Ustawa z dnia 14 grudnia 1995 r. o urzędzie Ministra Obrony Narodowej. (1995). Dz.U. z 1996 r., $\mathrm{Nr}$ 10, poz. 56.

Ustawa z dnia 21 czerwca 2013 r. o zmianie ustawy o urzędzie Ministra Obrony Narodowej oraz niektórych innych ustaw. (2013). Dz.U. z 2013 r., poz. 852.

Ustawa z dnia 21 listopada 1967 r. o powszechnym obowiązku obrony Polskiej Rzeczypospolitej Ludowej. (1967). Dz.U. z 1967, Nr 44, poz. 220.

Ustawa z dnia 24 maja 2007 r. o zmianie ustawy o powszechnym obowiązku obrony Rzeczypospolitej Polskiej oraz o zmianie niektórych innych ustaw. (2007). Dz.U. z 2007 r., Nr 107, poz. 732.

Ustawa z dnia 29 maja 1989 r. o przekazaniu dotychczasowych kompetencji Rady Państwa Prezydentowi Polskiej Rzeczypospolitej Ludowej i innym organom państwowym. (1989). Dz.U. z 1989, Nr 34, poz. 178.

Ustawa z dnia 3 grudnia 2010 r. o zmianie ustawy o wojewodzie i administracji rządowej w województwie oraz o zmianie niektórych innych ustaw. (2010). Dz.U. z 2011 r., Nr 22, poz. 114 .

Ustawa z dnia 7 kwietnia 1989 r. o zmianie Konstytucji Polskiej Rzeczypospolitej Ludowej. (1989). Dz.U. z 1989 r., Nr 19, poz. 101. 
Ustawa z dnia 9 listopada 2000 r. o bezpieczeństwie morskim. (2000). Dz.U. 2000, Nr 109, poz. 1156.

Wasilewski, A., Kuleta, D. (2003). Spór o miejsce i rolę Sztabu Generalnego WP w sprawie dowodzenia Siłami Zbrojnymi RP w latach 1990-2002. Myśl Wojskowa, 213-219.

Wikipedia. (2017). Krakowski Okręg Wojskowy. Pobrane z: https://pl.wikipedia.org/wiki/ Krakowski_Okręg_Wojskowy.

Winczorek, P. (2008). Komentarz do Konstytucji Rzeczypospolitej Polskiej z dnia 2 kwietnia 1997 r. Warszawa: Liber.

Witkowski, Z. (2006). Prezydent Rzeczypospolitej Polskiej. W: Z. Witkowski et al. (red.). Prawo konstytucyjne (415-442). Toruń: „Dom Organizatora” Towarzystwo Naukowe Organizacji i Kierownictwa Stowarzyszenie Wyższej Użyteczności.

Zarządzenie nr 67/PRM z dnia 29 grudnia 1990 r. w sprawie powołania Międzyresortowej Komisji do Spraw Reform w Organizacji Obrony Narodowej, niepublikowane. (1990).

Założenia Polskiej Polityki Bezpieczeństwa oraz Polityka Bezpieczeństwa i Strategia Obronna Rzeczypospolitej Polskiej z dnia 2 listopada 1992 r., niepublikowane. (1992).

Zarządzenie nr PF 1/MON z dnia 22 października 1992 r. w sprawie określenia kierowniczych organów wykonawczych oraz przeformowania Ministerstwa Obrony Narodowej. (1992).

Zarządzenie nr Z-4/MON Ministra Obrony Narodowej z dnia 15 lutego 2008 r. w sprawie szczegółowego zakresu działania, struktury organizacyjnej oraz siedziby Dowództwa Wojsk Lądowych. (2008). Dz. Urz. MON z 2008 r., nr 7, poz. 67.

Zarządzenie nr Z-5/MON Ministra Obrony Narodowej z dnia 15 lutego 2008 r. w sprawie szczegółowego zakresu działania, struktury organizacyjnej oraz siedziby Dowództwa Wojsk Lądowych. (2008). Dz. Urz. MON z 2008 r., nr 7, poz. 67.

Zarządzenie nr Z-5/MON Ministra Obrony Narodowej z dnia 15 lutego 2008 r. w sprawie szczegółowego zakresu działania, struktury organizacyjnej oraz siedziby Dowództwa Marynarki Wojennej. (2008). Dz. Urz. MON z 2008 r., nr 7, poz. 68.

Zarządzenie nr Z-6/MON Ministra Obrony Narodowej z dnia 15 lutego 2008 r. w sprawie szczegółowego zakresu działania, struktury organizacyjnej oraz siedziby Dowództwa Wojsk Lądowych. (2008). Dz. Urz. MON z 2008 r., nr 7, poz. 69.

Zarządzenie Prezydenta Rzeczypospolitej Polskiej z dnia 3 lipca 1991 r. w sprawie zarządzenia wyborów do Sejmu i Senatu Rzeczypospolitej Polskiej. (1991). Dz.U. z 1991 r., $\mathrm{Nr}$ 60, poz. 254. 